\title{
Interparietal Bone Variations in Accordance with their Ossification Centres in Human Skulls
}

\author{
Variaciones de los Huesos Interparietales de Acuerdo \\ con sus Centros de Osificación en Cráneos Humanos
}

\author{
Aaijaz Ahmed Khan*; Muzammil Ullah**; Mohd. Asnizam Asari* \& Asma Hassan*
}

KHAN, A. A.; ULLAH, M.; ASARI, M. A. \& HASSAN, A. Interparietal bones variations in accordance with their ossification centres in human skulls. Int. J. Morphol., 31(2):546-552, 2013.

SUMMARY: The upper interparietal segment of the squamous part of the occipital bone develops in membrane and the lower supraoccipital part develops in cartilage. According to the available literature, the interparietal segment is ossified from 2 to 3 pairs of ossification centres and each of these centres has 2 nuclei. Interparietal bone is formed due to failure of fusion of these centres and/or their nuclei with each other. Many variations of interparietal bone have been reported by many investigators. In the present study, out of 25 human skulls studied, six skulls had some interesting variations of interparietal bones. Four interparietal bones were found in one skull, 2 interparietal bones were observed in another skull and the remaining four skulls had a single interparietal (Os inca) bone at the lambda. In addition to interparietal bones, some sutural bones were also observed in three skulls. These variations were in accordance with the ossification centres of the membranous part of the occipital bone. By their location and shape it was concluded that they were formed due to failure of fusion of nuclei of the third pair centres of ossification with each other, with opposite fellow and with the second pair centers. It was further concluded that these cases of interparietal bones were different from what had been reported earlier by other researchers and this prompted the present report that may be found useful for anatomists, anthropologists, radiologists and neurosurgeons.

KEY WORDS: Centre; Interparietal; Occipital bone; Ossification; Skull.

\section{INTRODUCTION}

Many variations of interparietal bones have been described in the literature. These variations could be better understood by knowing the ossification centers of the membranous part of the occipital bone.

There are controversial views in the literature concerning the limits and ossification of the membranous portion of the human occipital bone, known as the interparietal. Gray (1860) was probably the first who described the ossification of the occipital bone in man. He considered that the whole of the squamous part of the occipital bone above the superior nuchal lines develops in membrane by 2 centres, one on each side, which become continuous with each other and with the supraoccipital cartilaginous part. Later on, many investigators supported the view that in human skull, the occipital bone above the superior nuchal lines ossifies in membrane (Schaffer et al., 1915; Frazer, 1937; Keith, 1948; Breathnach, 1965;
Hamilton, 1976). However, Brash (1951), Pal (1987) and Williams et al. (1989) stated that the part of the occipital bone above the highest nuchal lines develops in membrane. It is, therefore, controversial as to whether the part of the occipital bone between the superior and highest nuchal lines develops in membrane or in cartilage. This part of the occipital bone, which is denser, smoother and sometimes prominently bulged, is known as the torus occipitalis transversus; it forms a distinct projection in anthropoids and to a lesser extent in earlier races of man (Schaffer et al.).

Srivastava (1992) in his study on the ossification of the membranous portion of the squamous part of the occipital bone in man stated that the squamous part of the occipital bone consists of lower supraoccipital and upper interparietal parts. According to him, the supraoccipital develops both in cartilage and membrane. At the upper

\footnotetext{
* Department of Anatomy, School of Medical Sciences, Universiti Sains Malaysia, Kubang Kerian-16150, Kelantan, Malaysia.

** School of Medical Sciences, Universiti Teknogi Mara.

The study was carried in Department of Anatomy, PPSP, USM, Kempus Kesihatan, Kubang Kerian- 16150, KotaBharu, Kelantan, Malaysia in the year 2010.
} 
margin the bone lying between the superior and highest nuchal lines known as the torus occipitalis transversus is ossified in membrane by a pair of centres. This part of the supraoccipital represents the original membranous part of the primitive occipital bone of lower animals where the interparietals form part of the parietals. Regarding the ossification of membranous interparietal part, most of the authors (e.g. Ranke 1913; Brash 1951; Breathnach 1965; Srivastava 1992) believe that it develops above the superior nuchal line by two to three pairs of centers.

On the basis of anomalies seen in the interparietal region, Ranke (1913) described 3 pairs of centres of ossification and sometimes an occasional 4th pair of centre at the upper angle during the development of squamous part of the occipital bone. The 1st pair of centres appears in the cartilage rudiment of the supraoccipital and gives rise to the whole of the element except for a strip along the upper margin. The remaining 2 pairs of centres and the occasional single pair appear in the membranous interparietal part. According to him, the 4th pair, whenever present, may form the pre-interparietal bone. However, Srivastava (1977) suggested that membranous interparietal part develops from 6 centres including 2 centres for the pre-interparietal. Williams et al. also stated that the membranous part of the bone above the highest nuchal line consists of 2 elements, an interparietal and preinterparietal parts.

Srivastava (1992), described that the membranous part of occipital bone is ossified by 3 pairs of centres. According to him, the first pair of centres lies between the superior and highest nuchal lines and forms the intermediate segment; the second pair of centres lies above the highest nuchal lines, one on each side of the midline and form the lateral plate; the third pair forms the medial plate of the interparietal bone (Fig.1). According to him, the intermediate segment is probably never separates from the cartilaginous supraoccipital part. He further stated that the centres and their nuclei in the membranous part of the occipital bone above the supraoccipital part were paired centres. The medial and lateral nuclei of the 2 nd pair of centres will form the lateral plate, and upper and lower nuclei of the 3rd pair of centres will form the medial plate. The 2 medial plates are separated by the median fissure. The intermediate segment is separated from the lateral plate by the lateral fissure (Fig.1). Thus, the interparietal bone is formed by the lateral and medial plates together. Failure of fusion between these centres or their nuclei with each other and the supraoccipital part may give rise to various anomalies in the interparietal region. The anomalies found in the present study can be explained by the ossification of occipital bone described by Srivastava 1992.

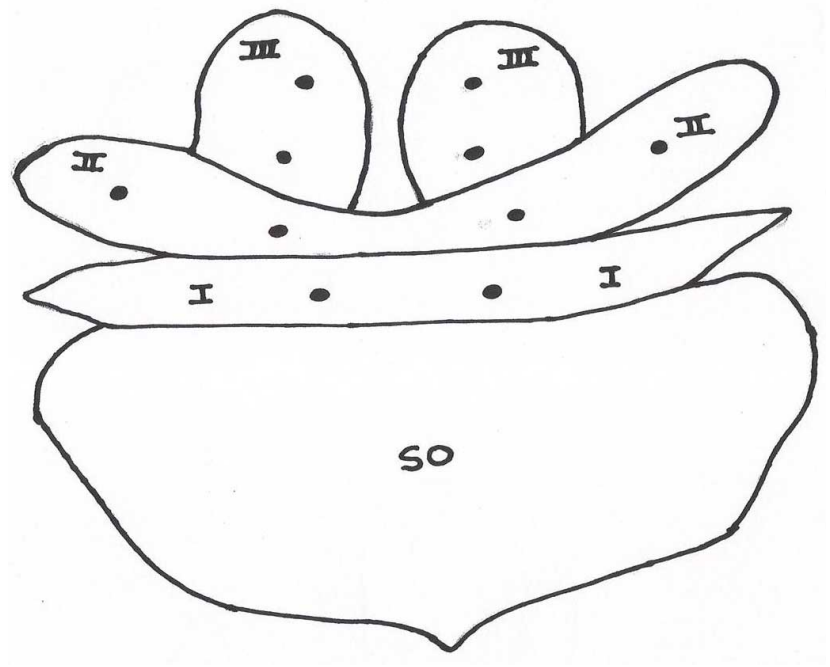

Fig. 1. An schematic diagram of the ossification centres of membranous part of the occipital bone above the supraoccipital bone. SO- supraoccipital, I- intermediate segment, II- second pair of centres with medial and lateral nuclei, III- third pair of centres with upper and lower nuclei.

\section{MATERIAL AND METHOD}

Twenty five human skulls obtained from the Department of Anatomy, Universiti Sains Malaysia were used in the study. The skulls were examined for the presence of interparietal bones. Different variations of the interparieatal bones were noted and photographed.

\section{RESULTS}

Out of 25 skulls examined, 6 skulls were found to have interparietal bones. In one skull (Case1) two separate symmetrical interparietal bones were noted to lie on either side of midline (Figs. 2 and 3). Their peripheral outline was irregular and appeared as processes projecting in the parietal bone.

In the second skull (Case 2), 4 different interparietal bones, 2 on each side of midline were observed (Figs. 4 and 5). The left interparietal bones were slightly larger than the right bones and the medially placed bone was larger than the bone on the lateral side. The shape of these interparietal bones was nearly similar to those found in case 1 .

In the third, fourth and fifth specimens (Cases 3, 4 and 5) a single interparietal bone was observed at the lambda 
(Figs. 6, 8 and 9). Its shape was nearly similar to the above two cases. In case 3 , numerous Wormian bones were also observed in the lambdoid suture especially on the left side (Fig. 7). In case 4 (Fig. 8) a sutural bone was also found in the sagittal suture just in front of interparietal bone. In case5 , the interparietal bone was comparatively larger than the

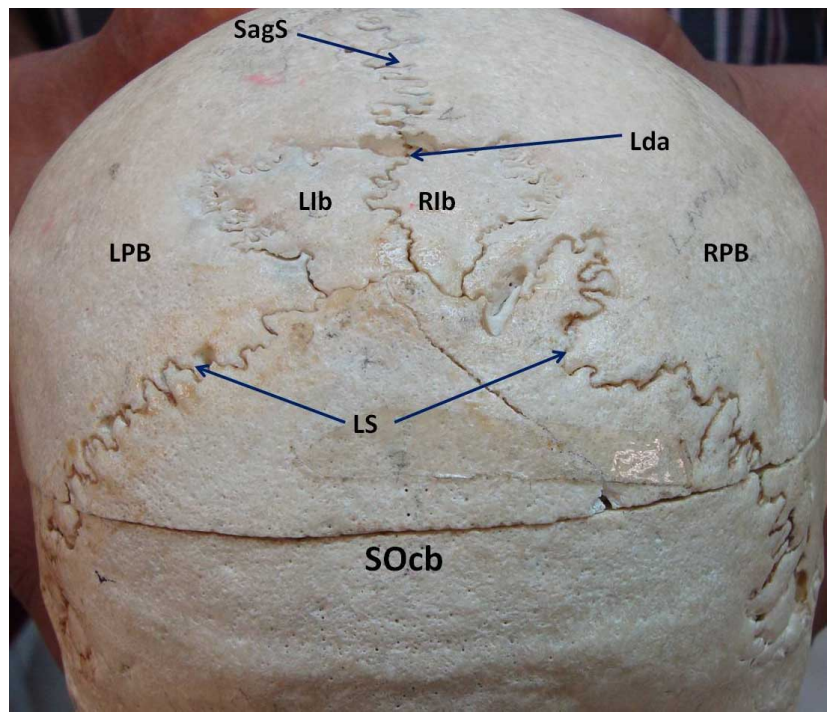

Fig. 2. Showing two interparietal bones. SagS- Sagital suture, LdaLamda, LS - Lambdoid Suture, LPB- Left parietal bone, RPBRight parietal bone, LIB- Left Interparietal bone, Rlb- Right Interparietal bone, $\mathrm{SOcb}$ - Squamous occipital bone.

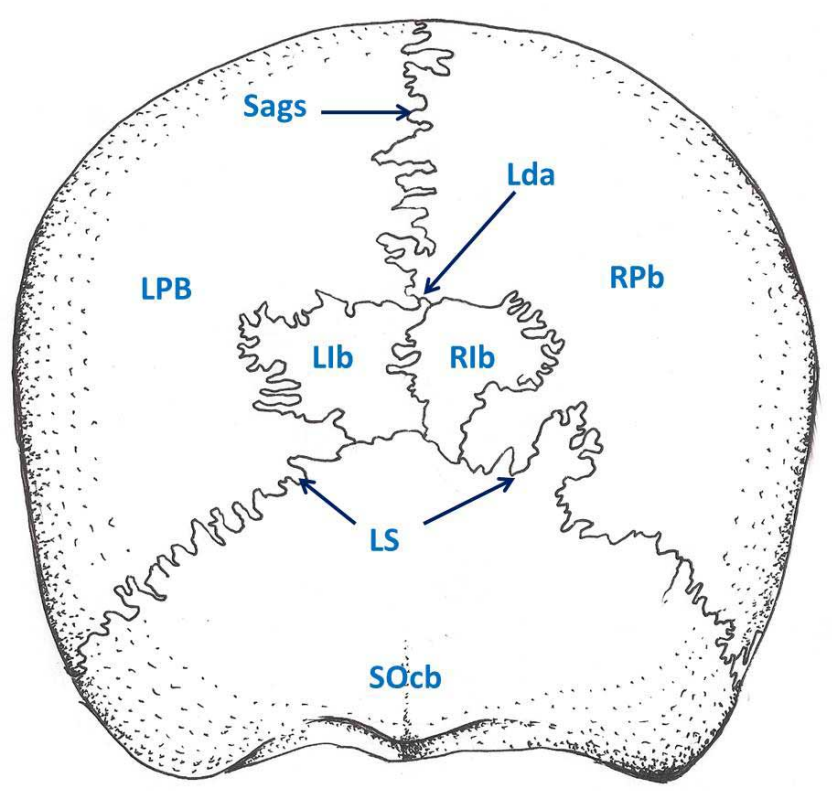

Fig. 3. A line diagram of Fig. 2, showing two interparietal bones SagS- Sagital suture, Lda- Lamda, LS, Lambdoid Suture, LPBLeft parietal bone, RPB- Right parietal bone, LIB- Left Interparietal bone, RIb- Right Interparietal bone, SOcb - Squamous occipital bone. cases 3 and 4 . In this skull a large parietal foramen was also noted on the left side (Fig. 9).

In the sixth skull (Case 6), a single interparietal bone was seen at the lambda (Fig. 10). Its shape was nearly similar to the left interparietal bones seen in cases 1 and 2 .

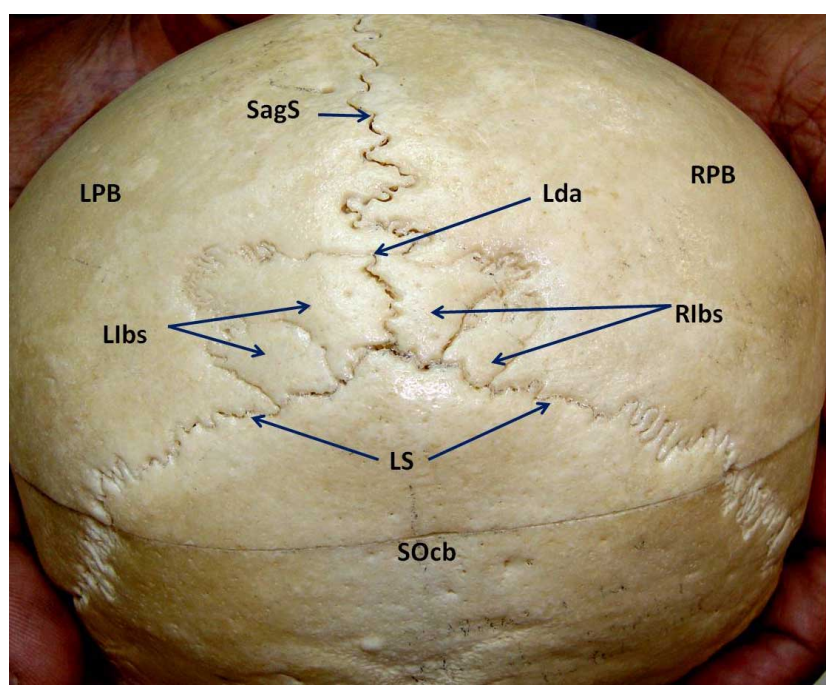

Fig. 4. Showing four interparietal bones. SagS- Sagital suture, LdaLamda, LS- Lambdoid Suture, LPB- Left parietal bone, RPB- Right parietal bone, Llbs- Left Interparietal bones, Rlbs- Right Interparietal bones, SOcb - Squamous Occipital bone.

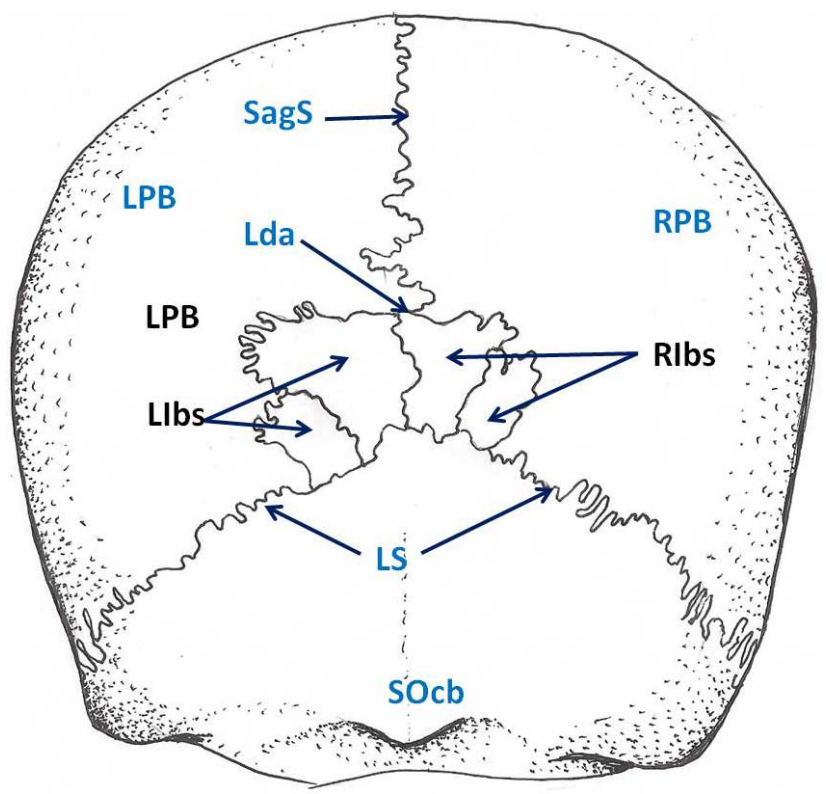

Fig. 5. A line diagram of Fig. 4 showing four interparietal bones. SagS- Sagital suture, Lda- Lamda, LS- Lambdoid Suture, LPBLeft parietal bone, RPB- Right parietal bone, LIbs- Left Interparietal bones, Rlbs- Right Interparietal bones, SOcb Squamous Occipital bone. 


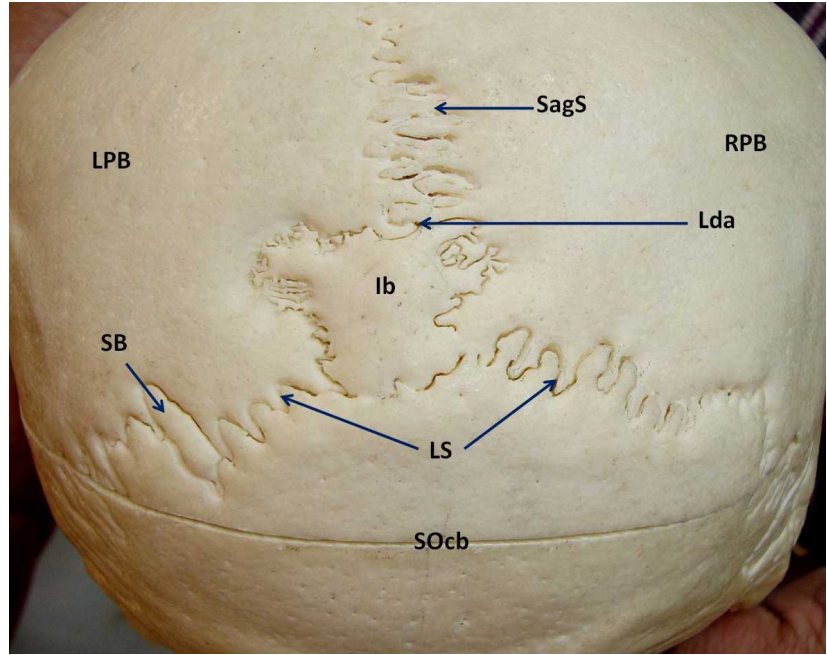

Fig. 6, Showing single interparietal bone. SagS- Sagital suture, Lda- Lamda, LS- Lambdoid Suture, LPB- Left parietal bone, RPBRight parietal bone, lb- Interparietal bone, SOcb - Squamous occipital bone, SB- Sutural bone.

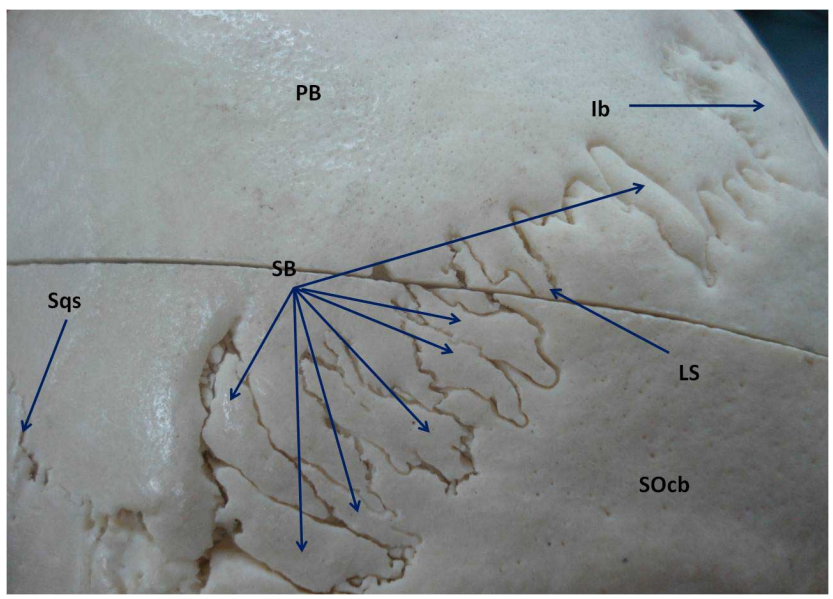

Fig. 7. Showing sutural bones in the left lmbdoid suture. PBParietal bone, SB - Sutural bones, lb- Interparietal bone, Sqs Squamosal suture, LS- lambdoid suture, SOcb- Squamous occipital bone.

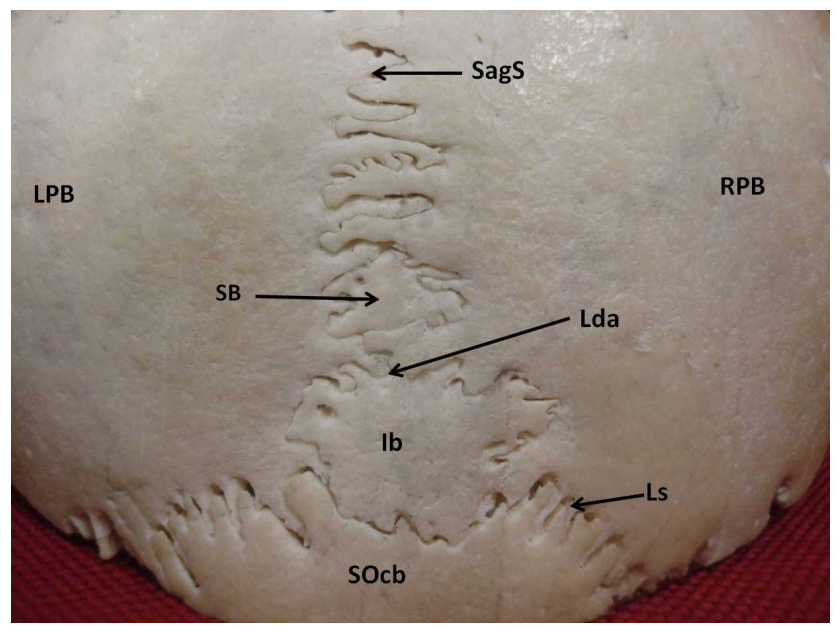

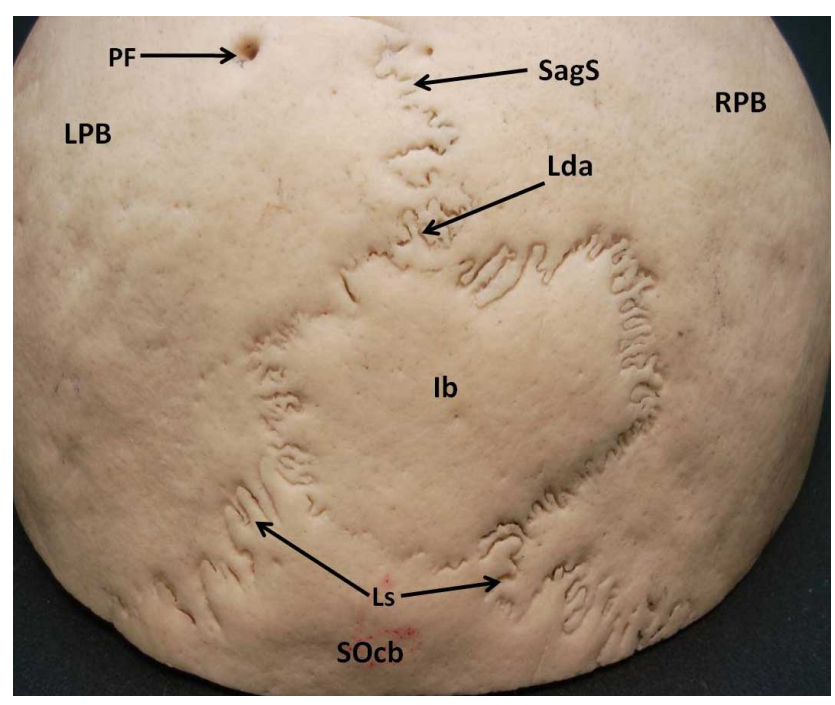

Fig. 9. Showing a single interparietal bone.SagS- Sagital suture, Lda- Lamda, Ls - Lambdoid suture LPB- Left parietal bone, RPBRight parietal bone, PF- Parietal foramen, Ib- Interparietal bone, SOcb - Squamous occipital bone.

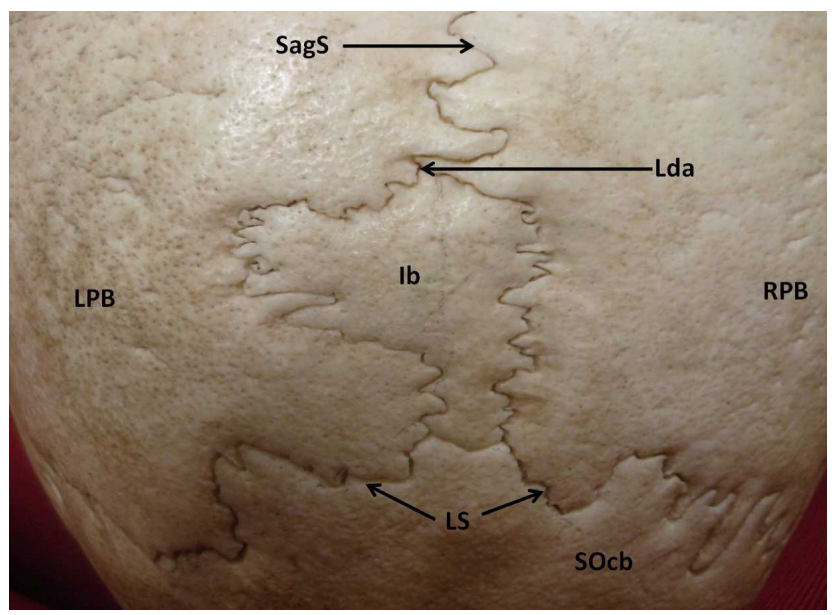

Fig. 10. Showing a single interparietal bone. SagS- Sagital suture, Lda- Lambda, LS- Lambdoid Suture, LPB- Left parietal bone, RPBRight parietal bone, Ib- Interparietal bone, SOcb - Squamous occipital bone.

Fig. 8. Showing a single interparietal bone with a sutural bone in the sagital suture. SagS- Sagital suture, SB- Sutural bone, LdaLamda, Ls - Lambdoid suture LPB- Left parietal bone, RPB- Right parietal bone, Ib- Interparietal bone, SOcb - Squamous occipital bone.

\section{DISCUSSION}

The variations of the interparietal bones found in the present study can be interpreted well in the light of ossification centres described by Srivastava (1992). 
According to Srivastava (1992), the membranous part of the occipital bone is ossified by 3 pairs of centres, which is in disagreement with the findings by Ranke (1913) and Breathnach (1965) who found 2 pairs of ossification centres for this part of the bone. Srivastava's first pair of centres appears in the early part of the 9th week in the region of external occipital protuberance on either side of the midline. This pair forms the intermediate segment (Fig-1), which lies between the superior and highest nuchal lines and is known as the torus occipitalis transversus. A second pair of centres appears one on each side of midline above the intermediate segment. Each of these centres consists of two nuclei, medial and lateral. These two nuclei coalesce and form the lateral plate of the interparietal bone. This corresponds to the upper part of the Ranke's 2nd pair of centres. However, Ranke did not describe subdivision of 2 nd pair of centres. The two parts, intermediate segment (IS) and lateral plate, which develop from the 1st and 2nd pair of centres respectively, are separated from each other by the lateral fissure (Fig.1). The third pair of centres described by Srivastava (1992) also had two nuclei, upper and lower and according to him they form the medial plate of the membranous part of the interparietal bone. This centre corresponds with the occasional centre described by Ranke (1913) and Pal et al. (1984).

The incidence of the interparietal bone varies among different population. According to Aycan (1993), it is 15\% in Nigerians (both the interparietal and pre-interparietal bones), 1.2\% in Europeans, $0.8 \%$ in Australians, $4.8 \%$ in Northern Americans and $2.4 \%$ in Indians (both the interparietal and pre-interparietal bones). In Turkish skulls this incidence has been observed to be $4 \%$ (6/150) by Cireli et al. (1985), 3.8\% (16/420) by Magden \& Müftüoglu (1990), and 6.59\% (6/91) by Aycan (1993). Similarly the incidences reported in the Indian skulls varied from $0.99 \%$ (Zambare 2001) to 2.6\% (Pal et al., 1984). In the present study, only 25 skulls were used and the interparietal bones were found in 6 cases. This is quite a high percentage of incidences. Because the sample in the present study was small (25 skulls only), it would not be proper to quote the incidence.

Various anomalies of the interparietal occurs when the 2nd and 3rd pair of centres fail to fuse with each other and with the intermediate segment and sometimes their nuclei fail to fuse with each other or to the opposite fellow to form the separate bone(s) in the interparietal region. According to Pal (1987), the failure of fusion between these pairs of centres and between these centres and supraoccipital part can give rise to a maximum of six pieces of bones (three on either side) in the interparietal region.

In the present study, the six cases of interparietal bone found were probably the anomalies involving the 3 rd pair of centres. In case-1 (Fig. 2) there were two separate interparietal bones below the lambda. In this case, it seems that the upper and lower nuclei of the 3rd pair of centres fused with each other but failed to fuse with the opposite fellow centres and the 2nd pair centres. In second case (Fig. 4) there were four interparietal bones. In this case, it appears that the upper and lower nuclei of 3rd pair failed to fuse with each other, and with the opposite pair and with the 2 nd pair centres. This resulted in the formation of 4 separate pieces of bones.

In case- 3, 4 and 5 (Figs. 6, 8,9), there was a single piece of interparietal bone at the lambda. In these three cases, it appears that the nuclei of the 3rd pair centres of both the sides fused with each other but failed to fuse with the 2nd pair centres as suggested by the Srivastava (1992). Case -6 (Fig. 10) showed a single interparietal bone on the left side. It seems that in this case, the left side nuclei of third pair fused with each other but failed to fuse with the right side nuclei in the midline and with second pair centres below.

Malhotra et al. (1978) reported a single large interparietal bone with large number of Wormian bones in the region of lambdoid suture. On the other hand, Saxena et al. (1986) and Srivatava (1977) reported a single interparietal bone below the lambda; they referred it as the pre-interparietal bone which develops from the occasional pair of centres as described by Ranke (1913) and Breathnach (1965). However, according to Srivastava (1992) this bone actually is the upper half of the central piece where the upper nuclei of the 3rd pair of centre have fused with each other but have failed to fuse with their lower nuclei, thus forming a separate interparietal bone below the lambda. According to Srivastava (1992), this bone is a part of the interparietal bone and is not a pre-interparietal bone. Thus, any centre or any nucleus developing independently or jointly with other centres in the interparietal region near the lambda or lambdoid suture should not be considered as a preinterparietal bone because they are the part of the interparietal bone. As such, 'Pre-interparietal' is a misnomer term and should be avoided and their incidence should not be reported separately (Ferruh et al. 1998). Pal et al. (1987) also suggested that the term pre-interparietal is misleading and the bone(s) should be referred the upper central piece or pieces of interparietal bone. Breathnach (1965) also considered the preinterparietal simply as an assumption based on anomalies. In view of the above, in the present study we did not use the term pre-interparietal although looking at their location and shapes, they may be considered as pre-interparietal bones.

All the bones developing in the region of the lambda and lambdoid suture outside the limits of the interparietal area (including the one found in case- 3 and 4 of the present study) are sutural or Wormian bones, which develop from their own separate ossification centres. 


\section{CONCLUSION}

It is concluded that interparietal bones can appear in various forms and shapes depending on the failure of fusion of ossification centres and their nuclei in the interparietal region. They may be like tongue-shaped processes projecting towards the parietal bones. The presence of these types of interparietal bones may lead to confusion in the diagnosis of fracture of skull in cases of head injuries.

\section{ACKNOWLEDGEMENTS}

Our sincere thanks to Dr. Ananada A. for drawing nice line diagrams of the photographs. We are also thankful to technologists, Mr. Mohd Harisal, Mr. Mohd Adi Azhari and Norhana binti Arshad, for arranging skulls and helping us in taking photographs. The study was carried out in the Department of Anatomy, PPSP, USM, Kempus Kesihatan, Kubang Kerian 16150, KotaBharu, Kelantan, Malaysia in the year 2010 with the help of incentive grant.

KHAN, A. A.; ULLAH, M.; ASARI, M. A. \& HASSAN, A. Variaciones de los huesos interparietales de acuerdo con sus centros de osificación en cráneos humanos. Int. J. Morphol., 31(2):546-552, 2013.

RESUMEN: El segmento interparietal superior de la porción escamosa del hueso occipital es de origen membranoso y la parte inferior supraoccipital se desarrolla en el cartílago. De acuerdo con la literatura disponible, el segmento interparietal se osifica a partir de 2 a3 pares de centros y cada uno de estos centros cuenta con 2 núcleos. El hueso interparietal se forma debido a la falta de fusión de estos centros y / o sus núcleos. Muchas variaciones de hueso interparietal han sido reportados por investigadores. En el presente estudio, de 25 cráneos humanos estudiados, seis cráneos presentaban algunas variaciones interesantes de huesos interparietales. Cuatro huesos interparietales fueron encontrados en un cráneo, dos huesos interparietales en un cráneo y cuatro cráneos presentaban un solo hueso interparietal (Os inca) en el lambda. Además, de los huesos interparietales, en tres cráneos se observaron huesos suturales. Estas variaciones estaban en relación con los centros de osificación de la parte membranosa del hueso occipital. Por su ubicación y forma, se concluyó que los huesos se formaron debido a la falta de fusión entre sí de los núcleos de los centros del tercer par de osificación, con otros opuestos y con los centros del segundo par. Se concluye, además, que estos casos de huesos interparietales eran diferentes de lo que se había informado anteriormente por otros investigadores y esto nos impulsó al estudio, el cual puede ser útil para anatomistas, antropólogos, radiólogos y neurocirujanos.

\section{PALABRAS CLAVE: Centro; interparietal; hueso occipital; osificación; Cráneo.}

\section{REFERENCES}

Aycan, K. Development of Interparietal bones and their variations. Erciyes Universities Saglik Billimleri Dergisis, 2:70-6, 1993.

Brash, J. C. Cunningham's Text Book ofAnatomy. $9^{\text {th }}$ edn. London, Oxford University Press, 1951. pp. 212-220.

Breathnach, A. S. Frazer's Anatomy of the Human Skeleton. $6^{\text {th }}$ edn. p. 190. London: J. \& A. Churchill, 1965.

Cireli, E.; Ustun, E. E. \& Tetik, S. Os occipital varyasyonlarive radyolojik Ozellikleri. Ege Universities Tip Faultesi Dergisi, 24:3-35, 1985.

Ferruh, Y.; Hulusi, E. \& Zehra, A. Tr. J. of Medical Sciences 28 505-509 @ TÜBITAK 505, 1998.

Frazer, J. E. Buchanan's Manual of Anatomy. $6^{\text {th }}$ edn. London, Bailliere, Tindall and Cox, 1937, pp. 172-178.

Gray, H. Anatomy, Descriptive and Surgical. $2^{\text {nd }}$ edn, Philadelphia, Blanchard and Lea, 1860, p. 61.
Hamilton, W.J. Textbook of Human Anatomy. $2^{\text {nd }}$ edn. London, Macmillan, 1976, p. 71.

Keith, A. Human Embryology and Morphology. $6^{\text {th }}$ edn. London, Edward Arnold, 1948. pp. 212-24.

Magden, O. \& Muftuoglu, A. Insan democraniumunda sutural ve epectal kemiklerin varyasyonlari. Istanbul Universities Cerrahpasa Tip Fakultesi Dergisi, 21:319-23, 1990.

Malhotra, V. K. Tewari, PS. Pandey, SN. \& Tewari, SP. Interparietal bone. Acta anat., 101:94-6, 1978

Pal, G. P. Variations of the interparietal bone in man. J. of Anat., 152:205-8, 1987.

Pal, G. P.; Tamankar, B. P.; Routal, R.V. \& Bhagwat, S. S. The ossification of the membranous part of the squamous occipital bone in man. J. Anat., 138:259-266, 1984.

Ranke, J. (1913) op cit. E. A. Schaffer, J. Symington \& T. H. Bryce in Quain's Elements of Anatomy. $11^{\text {th }}$ edn. London, Longmans, Green, 1915. V. 4. part I, pp. 53-5. 
KHAN, A. A.; ULLAH, M.; ASARI, M. A. \& HASSAN, A. Interparietal bones variations in accordance with their ossification centres in human skulls. Int. J. Morphol., 31(2):546-552, 2013.

Saxena, S. K.; Chowdhary, D.S. \& Jain, S.P. Interparietal bones in Nigerian Skulls. J. Anat., 144:235-7, 1986.

Schaffer, E. A.; Symington, J.; Bryce, T. H. Quain's Elements of Anatomy. $11^{\text {th }}$ edn. London, Longmans, Green, 1915. V. 4, part I, pp. 50-55.

Srivastava, H C. Ossification of the membranous portion of the squamous part of the occipital bone in man. J. Anat., 180:21924, 1992.

Srivastava, H. C. Development of the ossification centres in the squamous portion of the occipital bone in man. J. Anat., 124:643-9, 1977.

Williams, P. L.; Warwick, R.; Dyson, M. \& Bannister, L. H. Gray's Anatomy. $37^{\text {th }}$ edn. London, Churchill Livingstone, 1989. pp. 371-373.

Zambare, B.R. Incidence of Interparietal Bones in Adult Skulls. J. Anat. Soc. India, 50(1):11-2, 2001.
Correspondence to:

Aaijaz Ahmed Khan, Senior Lecturer

Department of Anatomy

Universiti Sains Malaysia

Kubang Kerian - 16150

Kelantan

MALAYSIA

Ph- 0060-9-7676080,

Mobile $N^{\circ} 0060179031662$

Fax- 006097653370

Email ID: aaijazk@gmail.com
aaijaz@kb.usm.my

Received: 18-03-2012

Accepted: 29-01-2013 